\title{
Learned to Use or Learned not to Use? \\ - An Application of the Wiles Test on Graduates of China's Newly-upgraded Universities
}

\author{
Xiaowen Zhu ${ }^{\text {a1 }}$, Zhiwen Zhu ${ }^{\text {b2 }}$ \\ ${ }^{a}$ Department of Enrollment \& Employment Huaiyin Institute of Technology Huaian, China \\ ${ }^{b}$ School of Economics \& Management Huaiyin Institute of Technology Huaian, China
}

\begin{abstract}
The human capital hypothesis and the screening hypothesis were commonly used to explain the positive effect of education level on individual incomes in the field of education economics. Using graduates of the newlyupgraded universities of China as the sample, this paper tested the two contending hypothesis. The results were in favor of the human capital hypothesis, which indicated higher education was rather a production means than merely a signal of productivity for graduates of these universities.
\end{abstract}

Index Terms: Human capital hypothesis; screening hypothesis; Wiles test; job match; newly-upgraded colleges

(C) 2013 Published by MECS Publisher. Selection and/or peer review under responsibility of the International Conference on E-Business System and Education Technology

\section{INTRODUCTION}

The human capital hypothesis $(\mathrm{HCH})$ and the screening hypothesis $(\mathrm{SH})$ are commonly used to explain the positive effect of education level on individual incomes in the field of education economics. According to the $\mathrm{HCH}$, individuals invest in their human capital via education, learning, training or working, which improves their productivities and hence enables them acquire higher returns in labor markets [1]. However, the SH contends that employers use education as productivity signals screening job applicants in labor markets with asymmetric information [2].

Wiles (1974) designed a method to test the two contending hypothesis. The idea of Wiles test is: If the SH were true, the productivities and incomes of college graduates employed in positions unmatched with their fields of study would be indifferent from those employed in positions matched with their fields of study [3]. The Wiles test had been replicated many times with different samples since 1974; however, the results are still inconclusive,

This study is sponsored by the Philosophy and Social Science Foundation for Higher Education of Jiangsu Province of China (Grant No. 09SJB880013).

* Corresponding author.

E-mail address: ${ }^{1}$ zhuxiaowen8@163.com, ${ }^{2}$ zhu_zhiwen@pku.edu.cn 
for instance, in [4] and [5] versus [6].

This paper will reexamine the Wiles test by using the sample of graduates of China's newly-upgraded universities (NUs). Because most NUs were established by merging and upgrading several three-year colleges, which used to emphasize the trainings of occupational and application skills, since Chinese Government launching an extensive expansion of higher education in 1999. As such, many NUs are faced with the question whether transforming to emphasize the general education and the trainings of academic skills [7].

At this point, conducting a Wiles test on graduates of NUs would be instructive to answer this question. Obviously, if the results of Wiles test support the $\mathrm{HCH}$, the NUs should maintain their previous principles and objectives of education. Otherwise, if the results support the $\mathrm{SH}$, they should change their previous principles and objectives of education after upgrading.

\section{Research Design}

\section{A. Data and Samples}

We undertook a survey of graduates' seeking jobs in 6 NUs at Jiangsu Province of China in June 2010. By July 2010, a total of 2572 valid questionnaires had been collected, of which $68.5 \%$ had confirmed their next career or study future prospects, while $50.9 \%$ had signed their first job contract after graduation. We dropped samples having not signed a job contract and outliers whose starting monthly salaries are fewer than 500 or more than 15000 yuan, leaving 1276 observations in the database.

\section{B. Variables and Measures}

1) Dependent variable: Income was used as the dependent variable, which was measured by the respondent's self-reported starting monthly salary.

2) Explanatory variable: Job match index was used as the explanatory variable, which indicates the extent of a job matching with the respondent's field of study. In this study such an index was measured based on the work of Richards (1984) in which respondents were asked to report whether their current occupation was matched with their qualification in terms of status and pay, usefulness of the skills acquired in their academic work and the relationship between their job and the field of study [8]. A five point scale was used as follows: 1much unmatched with, 2 - unmatched with, 3 - uncertain, 4 - matched with, 5 - much matched with. A dummy variable was used with 1 indicating the scale point equals 3,4 or 5 and 0 indicating the scale point equals 1 or 2 .

3) Control variables:

a) Major field of study: We divided majors using Biglan's (1973) typology of academic fields [9]. Categories introduced included soft-pure (e.g. literature, history), soft-applied (e.g. economics, management), hard-pure (e.g. physics, chemistry) and hard-applied (e.g. computer science, electronics, mechanical engineering).

b) Gender: Respondents were divided into two groups, the male and the female, according to their gender.

c) Enrollment type: A dummy variable was used with 1 indicating state planning and 0 indicating nonstate planning.

d) Family habitation: A dummy variable was used with 1 indicating urban area and 0 indicating rural area.

e) Family income: A dummy variable was used with 1 indicating high income (annual income $\geq 50000$ yuan) and 0 indicating low income (annual income $<50000$ yuan).

f) Family social connections: A dummy variable was used with 1 indicating "extensive" or "very extensive" and 0 indicating "ordinary", "few" or "very few".

g) Parents' education level: A dummy variable was used with 1 indicating high education level (either of parents is over senior high school level) and 0 indicating low education level (both of parents are under college level). 
h) Self-esteem: A five point scale based on Rosenberg (1965) was designed to measure self-esteem [10]. A dummy variable was used with 1 indicating high self-esteem (average point $\geq 2.5$ ) and 0 indicating low selfesteem (average point $<2.5$ ).

i) Academic record: A dummy variable was used with 1 indicating excellent academic record (grade point average ranking at the top 25\%) and 0 indicating ordinary or bad academic record (grade point average ranking below the top 25\%).

j) College English Test: A dummy variable was used with 1 indicating possessing and 0 indicating not possessing a band 6 certificate of College English Test.

k) Occupational skills certificate: A dummy variable was used with 1 indicating possessing at least one and 0 indicating not possessing any occupational skills certificate.

1) $C C P$ member: A dummy variable was used with 1 indicating being and 0 indicating not being a CCP member.

m) Student leader: A dummy variable was used with 1 indicating having been and 0 indicating having not been a student leader.

n) Practice or internship: A dummy variable was used with 1 indicating having and 0 indicating not having practice or internship experiences.

o) Employment area: A dummy variable was used with 1 indicating developed areas and 0 indicating developing areas.

p) Employment place: A dummy variable was used with 1 indicating large and medium-sized cities and 0 indicating county seats, villages and towns.

q) Public/private employment: A dummy variable was used with 1 indicating public employment (including state-owned enterprises, government sponsored institutions and government agencies) and 0 indicating private employment (including private enterprises, township and village enterprises and contractual joint ventures).

r) Job seeking times: The frequency of a respondent submiting his/her resume.

s) Job seeking expenses: The money (thousand yuan) a graduate paid for finding his/her job.

t) Job information sources: Four dummy variables were used: (1) Source-from-college, with 1 indicating obtaining job informations from colleges, (2) Source-from-internet, with 1 indicating obtaining job informations from internet, (3) Source-from-relations, with 1 indicating obtaining job informations from relatives or friends, (4) Other-sources, with 1 indicating obtaining job informations from sources other than above. Other-sources was used as the reference dummy variable.

\section{Model}

A semi-logarithmic regression model was developed for parameter estimation as follow

$$
\ln (\mathrm{y}) \quad . \quad \mathrm{x}^{\prime}
$$

Where $\mathrm{y}$ stands for the explained variable (Income), $\mathrm{x}$ the explanatory variable (Job match index), the constant term, the disturbance term, the regression coefficient of the explanatory variable, which is also the parameter mostly concerned in this study. is a vector of control variables and is the vector of regression coefficients for these control variables.

Major field of study and Gender did not enter (1) as control variables directly; nevertheless, they are used as two grouping variables for the convenience of comparisons between different majors or genders.

\section{Results}

We had four findings based on the regression results shown in Tab. 1: (1) coefficients of Job match index - the explanatory variable - were positive and statistically significant for all groups but "soft-pure" $(\mathrm{p}<0.05) ;(2)$ 
controlling Gender, coefficients of Job match index were more significant for application-oriented disciplines ("soft-applied" and "hard-applied") than for theory-oriented disciplines ("soft-pure" and "hard-pure"), which implied that the income of graduates from application-oriented disciplines (vs. theory-oriented disciplines) were more prone to be affected by Job match index; (3) controlling Major field of study, coefficients of Job match index were more significant for males than for females, which implied that the income of male (vs. female) graduates were more prone to be affected by Job match index; (4) coefficients of Academic record were statistically significant for most groups.

TABLE I. REGRESSION RESULTS

\begin{tabular}{|c|c|c|c|c|c|c|c|c|}
\hline \multirow{2}{*}{ Independent Variables $^{d}$} & \multicolumn{2}{|c|}{ Soft-pure ${ }^{a, b, c}$} & \multicolumn{2}{|c|}{ Soft-applied ${ }^{\text {a, b,c }}$} & \multicolumn{2}{|c|}{ Hard-pure $^{\text {a, b, c }}$} & \multicolumn{2}{|c|}{ Hard-applied ${ }^{\text {a, b, c }}$} \\
\hline & Male & Female & Male & Female & Male & Female & Male & Female \\
\hline Job match index & $\begin{array}{c}0.07 \\
(0.46)\end{array}$ & $\begin{array}{c}-0.04 \\
(-0.38)\end{array}$ & $\begin{array}{l}0.26 \\
(3.45)\end{array}$ & $\begin{array}{l}0.20 \\
(2.71)\end{array}$ & $\begin{array}{l}0.23 \\
(2.93)\end{array}$ & $\begin{array}{l}0.19 \\
(2.13)\end{array}$ & $\begin{array}{l}0.15 \\
(3.28)\end{array}$ & $\begin{array}{l}0.18 \\
(2.85)\end{array}$ \\
\hline Academic record & $\begin{array}{l}0.18 \\
(1.51)\end{array}$ & $\begin{array}{l}0.24 \\
(2.55)\end{array}$ & $\begin{array}{l}0.15 \\
(2.32)\end{array}$ & $\begin{array}{l}0.13 \\
(1.69)\end{array}$ & $\begin{array}{l}0.17 \\
(2.30)\end{array}$ & $\begin{array}{l}0.12 \\
(1.39)\end{array}$ & $\begin{array}{l}0.10 \\
(1.87)\end{array}$ & $\begin{array}{c}0.09 \\
(1.43)\end{array}$ \\
\hline Family income & $\begin{array}{l}0.17 \\
(1.74)\end{array}$ & $\begin{array}{l}0.26 \\
(2.08)\end{array}$ & $\begin{array}{l}0.13 \\
(2.16)\end{array}$ & $\begin{array}{l}0.09 \\
(1.29)\end{array}$ & $\begin{array}{l}0.10 \\
(1.42)\end{array}$ & $\begin{array}{l}0.18 \\
(1.80)\end{array}$ & $\begin{array}{l}0.10 \\
(2.39)\end{array}$ & $\begin{array}{l}0.07 \\
(1.38)\end{array}$ \\
\hline Self-esteem & $\begin{array}{l}0.21 \\
(1.29)\end{array}$ & $\begin{array}{l}0.24 \\
(1.76)\end{array}$ & $\begin{array}{l}0.17 \\
(2.22)\end{array}$ & $\begin{array}{l}0.16 \\
(2.10)\end{array}$ & $\begin{array}{l}0.24 \\
(2.87)\end{array}$ & $\begin{array}{c}0.12 \\
(1.44)\end{array}$ & $\begin{array}{l}0.20 \\
(4.16)\end{array}$ & $\begin{array}{l}0.11 \\
(1.80)\end{array}$ \\
\hline College English Test & $\begin{array}{l}0.28 \\
(2.78)\end{array}$ & $\begin{array}{l}0.26 \\
(1.77)\end{array}$ & $\begin{array}{l}0.14 \\
(1.99)\end{array}$ & $\begin{array}{c}0.13 \\
(1.56)\end{array}$ & $\begin{array}{c}0.10 \\
(0.74)\end{array}$ & $\begin{array}{c}0.18 \\
(1.77)\end{array}$ & $\begin{array}{l}0.14 \\
(2.81)\end{array}$ & $\begin{array}{l}0.13 \\
(1.75)\end{array}$ \\
\hline CCP member & $\begin{array}{l}0.17 \\
(1.93)\end{array}$ & $\begin{array}{l}0.05 \\
(0.55)\end{array}$ & $\begin{array}{l}0.22 \\
(3.12)\end{array}$ & $\begin{array}{l}0.16 \\
(1.72)\end{array}$ & $\begin{array}{l}0.16 \\
(1.91)\end{array}$ & $\begin{array}{l}0.38 \\
(2.28)\end{array}$ & $\begin{array}{l}0.17 \\
(2.48)\end{array}$ & $\begin{array}{l}0.22 \\
(2.87)\end{array}$ \\
\hline Practice or internship & $\begin{array}{l}0.14 \\
(1.78)\end{array}$ & $\begin{array}{l}0.19 \\
(1.93)\end{array}$ & $\begin{array}{c}0.16 \\
(1.89)\end{array}$ & $\begin{array}{l}0.11 \\
(1.37)\end{array}$ & $\begin{array}{l}0.13 \\
(1.79)\end{array}$ & $\begin{array}{l}0.12 \\
(1.24)\end{array}$ & $\begin{array}{l}0.17 \\
(3.82)\end{array}$ & $\begin{array}{l}0.121 \\
(1.81)\end{array}$ \\
\hline Employment area & $\begin{array}{l}0.32 \\
(2.33)\end{array}$ & $\begin{array}{l}0.25 \\
(2.36)\end{array}$ & $\begin{array}{l}0.25 \\
(3.51)\end{array}$ & $\begin{array}{l}0.16 \\
(2.31)\end{array}$ & $\begin{array}{l}0.19 \\
(2.59)\end{array}$ & $\begin{array}{l}(1.24) \\
0.22 \\
(1.87)\end{array}$ & $\begin{array}{l}(3.02) \\
0.09 \\
(2.01)\end{array}$ & $\begin{array}{c}\frac{(1.01)}{0.10} \\
(1.60)\end{array}$ \\
\hline Employment place & $\begin{array}{c}0.19 \\
(1.45)\end{array}$ & $\begin{array}{l}0.20 \\
(1.63)\end{array}$ & $\begin{array}{l}0.12 \\
(1.72)\end{array}$ & 0.26 & $\begin{array}{l}0.14 \\
(2.09)\end{array}$ & $\begin{array}{c}0.08 \\
(0.72)\end{array}$ & $\begin{array}{l}0.12 \\
(2.66)\end{array}$ & $\begin{array}{l}0.13 \\
(2.16)\end{array}$ \\
\hline Public/private employment & $\begin{array}{l}0.19 \\
(1.83)\end{array}$ & $\begin{array}{l}0.18 \\
(1.80)\end{array}$ & $\begin{array}{l}-0.05 \\
(-0.55)\end{array}$ & $\begin{array}{l}0.10 \\
(1.30)\end{array}$ & $\begin{array}{l}0.24 \\
(2.37)\end{array}$ & $\begin{array}{l}-0.02 \\
(-0.13)\end{array}$ & $\begin{array}{c}0.06 \\
(1.15)\end{array}$ & $\begin{array}{c}0.10 \\
(1.49)\end{array}$ \\
\hline Job seeking times & $\begin{array}{l}0.07 \\
(0.64)\end{array}$ & $\begin{array}{l}0.24 \\
(2.33)\end{array}$ & $\begin{array}{l}0.10 \\
(1.09)\end{array}$ & $\begin{array}{l}0.22 \\
(2.81)\end{array}$ & $\begin{array}{l}0.17 \\
(2.23)\end{array}$ & $\begin{array}{l}0.37 \\
(3.07)\end{array}$ & $\begin{array}{l}0.16 \\
(3.09)\end{array}$ & $\begin{array}{l}0.19 \\
(2.70)\end{array}$ \\
\hline Job seeking expenses & $\begin{array}{l}0.30 \\
(1.71)\end{array}$ & $\begin{array}{l}0.21 \\
(2.16)\end{array}$ & $\begin{array}{l}0.18 \\
(2.21)\end{array}$ & $\begin{array}{c}-0.04 \\
(-0.59)\end{array}$ & $\begin{array}{c}0.06 \\
(0.83)\end{array}$ & $\begin{array}{l}0.32 \\
(3.04)\end{array}$ & $\begin{array}{l}0.07 \\
(1.66)\end{array}$ & $\begin{array}{c}0.08 \\
(1.26)\end{array}$ \\
\hline Source-from-college & $\begin{array}{l}0.21 \\
(1.69)\end{array}$ & $\begin{array}{l}0.16 \\
(1.37)\end{array}$ & $\begin{array}{l}0.13 \\
(1.63)\end{array}$ & $\begin{array}{l}0.16 \\
(2.14)\end{array}$ & $\begin{array}{l}0.14 \\
(1.72)\end{array}$ & $\begin{array}{l}0.18 \\
(1.62)\end{array}$ & $\begin{array}{l}0.13 \\
(2.48)\end{array}$ & $\begin{array}{l}0.15 \\
(2.01)\end{array}$ \\
\hline Constant & $\begin{array}{l}6.72 \\
(29.23)\end{array}$ & $\begin{array}{l}6.71 \\
(49.81)\end{array}$ & $\begin{array}{l}7.04 \\
(90.84)\end{array}$ & $\begin{array}{l}6.90 \\
(66.76)\end{array}$ & $\begin{array}{l}6.85 \\
(70.18)\end{array}$ & $\begin{array}{l}6.74 \\
(52.54)\end{array}$ & $\begin{array}{l}6.78 \\
(84.50)\end{array}$ & $\begin{array}{l}6.80 \\
(87.02)\end{array}$ \\
\hline $\mathrm{N}$ & 71 & 84 & 187 & 143 & 118 & 88 & 375 & 210 \\
\hline $\mathrm{R}^{2}$ & 0.48 & 0.37 & 0.30 & 0.35 & 0.54 & 0.44 & 0.32 & 0.36 \\
\hline F test & $2.36^{\prime \prime \prime}$ & $2.68^{* * *}$ & $5.72^{* \cdots}$ & $3.33^{* \ldots \cdots}$ & $4.72^{* \cdots}$ & $2.82^{* \cdots}$ & $6.92^{* \cdots *}$ & $7.17^{* * \pi}$ \\
\hline
\end{tabular}

a. The significance level of $1 \%, 1 \%, 5 \%$ and $10 \%$ are respectively noted by $* * *, * *, *$ and $\uparrow$.

b. Standardized coefficients.

c. The numbers in parentheses are $t$ ratios based on Huber-White robust standard errors.

d. Statistically insignificant control variables $(p>0.1)$ are not listed in the table.

Miller and Volker (1984) considered that graduates of humanities were not suitable for the Wiles test, because the professional education of humanities could not improve students' occupational skills immediately [6]. As such, the regression results for group "soft-pure" could not be the evidences supporting or rejecting the Wiles test. Based on that, the results of Wiles test in our study are more likely to support the $\mathrm{HCH}$. 


\section{Discussions and Conclusions}

\section{A. Robustness}

To check the robustness of regression results, two transformations were made.

1) Redefine the explanatory variable: The dummy variable for Job match index was redefined, with 1 indicating the scale point equals 4 or 5 and 0 indicating the scale point equals 1,2 or 3 . The regression results were not changed qualitatively.

2) Put grouping variables into (1) directly: Generating three dummy variables for Major field of study, then put Major field of study, Gender, the interaction term Gender * Job match index and three interaction terms between Job match index and the dummy variables of Major field of study into (1). Results showed that the explanatory variable was still significant $(\mathrm{p}<0.01)$, and all interaction terms were significant $(\mathrm{p}<0.05)$, which were consistent with the results in Tab. 1.

\section{B. Self-selection bias}

Because the six NUs surveyed are all situated at Jiangsu Province, and we kept only samples having signed a job contract, innegligible sample bias or self-selection bias may exist. In regard to this, Heckman correction was used [11]. The results were not changed qualitatively.

\section{Conclusions and Implications}

The results indicated that graduates employed in positions matched with their fields of study earned more than graduates employed in positions unmatched with their fields of study. Thus according to the logic of Wiles test, we could draw the conclusion that the $\mathrm{HCH}$ is more likely to be supported than the SH, which also implies higher education is rather a production means than a signal of productivity for graduates of NUs.

This conclusion has practical implications for the NUs and their graduates.

1) For the NUs: For occupational skills are very important for the employment outcome of graduates, the NUs should continue to emphasize the trainings of occupational and application skills instead of transforming hastily to the general education and the trainings of academic skills. For this purpose, the NUs should adjust their curriculum and faculty structure to accommodate with the skill demands in labor markets.

2) For the graduates: Graduates of the NUs should seek jobs as matched with their major fields of study as possible. Because according to the $\mathrm{HCH}$, only at such jobs could their human capital accumulated through higher education work well.

\section{References}

[1] G. Becker, Human Capital. New York: Columbia University Press, 1964.

[2] M. Spence, "Job market signaling," The Quarterly Journal of Economics, vol. 87, no. 3, pp. 355-374, August, 1973.

[3] P. Wiles, "The correlation between education and earnings: the External-Test-Not-Content hypothesis," Higher Education, vol. 3, no. 1, pp. 43-58, 1974.

[4] G. Arabsheibani, "The Wiles test revisited," Economics Letters, vol. 29, pp. 361-364, 1989.

[5] W. N. Grubb, "The returns to education in the sub-baccalaureate labor market," Economics of Education Review, vol. 16, no. 3, pp. 231-245, 1997.

[6] P. W. Miller and P. A. Volker, "The screening hypothesis: an application of the Wiles test," Economic Inquiry, vol. 22, pp. 121-127, 1984. 
[7] W. H. Xie, "Match and adaption - the two patterns of relationship between trainings in higher education and the labor market," Peking University Education Review, no. 4, pp. 9-11, 2004.

[8] E. Richards, "Early employment situations and work role satisfaction among recent college graduates," Journal of Vocational Behavior, vol. 24, pp. 305-318, 1984.

[9] A. Biglan, "The characteristics of subject matter in different academic areas," Journal of Applied Psychology, vol. 57, no. 3, pp. 195-203, 1973.

[10] M. Rosenberg, Society and the Adolescent Self-image. Princeton, NJ: Princeton University Press, 1965.

[11] J. Heckman, "Sample selection bias as a specification error," Econometrica, vol. 47, pp. 153-161, 1979. 